\title{
HHV-8 and EBV Positive Lymphoproliferative Disease: A Challenging Case
}

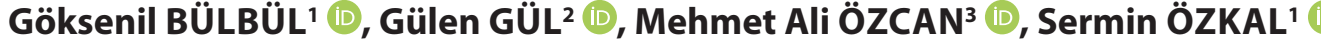 \\ Department of Pathology, 'Dokuz Eylül University, School of Medicine, IZMIR, TURKEY, ${ }^{2}$ University of Health Sciences, Tepecik Training and Research Hospital, IZMIR, TURKEY \\ ${ }^{3}$ Department of Hematology, Dokuz Eylul University, School of Medicine, IZMIR, TURKEY
}

This case report has been submitted as an e-poster to the $30^{\text {th }}$ National Pathology Congress, which has organized by the Federation of Pathology Societies and the Turkish Pathology Society and was held online on 20-23 May, 2021.

\section{ABSTRACT}

Human herpes virus-8 (HHV-8) is linked to four lymphoproliferative diseases: primary effusion lymphoma, HHV-8 positive multicentric Castleman disease (MCD), HHV-8 positive diffuse large B cell lymphoma and HHV-8 positive germinotropic lymphoproliferative disorder (GLPD). The diagnosis of HHV-8 associated lymphoproliferative diseases is quite challenging because each entity is rare and has a wide morphological spectrum. Our aim is to emphasize the overlapping histopathological features of MCD and GLPD as well as to underline the importance of clinicopathological correlation in case these two entities cannot be distinguished by pathological examination.

We present here a case of an 82-year-old male patient who was examined for weight loss and multiple lymphadenopathy. Histopathological examination of the axillary lymph node revealed lymphoid follicle structures of varying shapes and sizes, including some atrophic germinal centers. Plasmablast-like cells were notable in some of these areas. HHV-8 and Epstein Barr Virus (EBV) positivity were noted in some of these cells and in a small number of cells in the mantle zone. Based on these findings; a diagnosis of "HHV-8 and EBV positive lymphoproliferative disease" was established.

Since HHV-8 positive MCD and GLPD have similar histopathological features, it may not be possible to distinguish these two entities by histopathological examination only. At this point, the importance of clinicopathological correlation becomes more evident, especially in the determination of the treatment protocol to be applied to the patient.

Keywords: Castleman disease, Germinotropic lymphoproliferative disorder, EBV, HHV-8

\section{INTRODUCTION}

Human herpesvirus-8 (HHV8) is a herpes virus that infects the endothelium, lymphocytes, keratinocytes and bone marrow stromal cells. It is associated with four lymphoproliferative diseases: primary effusion lymphoma, HHV-8 positive multicentric Castleman disease (MCD), HHV-8 positive diffuse large B cell lymphoma and HHV8 positive germinotropic lymphoproliferative disorder (GLPD) $(1,2)$.

The Epstein Barr Virus (EBV) is also a lymphotropic virus from the herpesvirus family like HHV8 (3). Although both viruses are associated with various lymphoid diseases, HHV8 + / EBV + lymphoproliferation is a rare entity (4).

Because of its rarity, we present a case co-infected with HHV8 and EBV resulting in a differential diagnosis difficulty due to the similar histopathological features of HHV-8 associated lymphoproliferative diseases.

\section{CASE REPORT}

Here we report a case of an 82-year-old male from İzmir/ Turkey diagnosed with schizophrenia, Parkinson's disease and diabetes mellitus and who had been taking medications for many years. He presented to a physician with increasing weight loss for the last one year in addition to fatigue. It was also learned that his brother had a diagnosis of lymphoma. Physical examination revealed conglomerated and fixed multiple lymphadenopathies, the largest of which was $4 \mathrm{~cm}$ in the right inguinal region and $1 \mathrm{~cm}$ in the left supraclavicular region. Peripheral blood test revealed the following: hemoglobin $9.9 \mathrm{~g} / \mathrm{dL}$, white blood cells 13,200/ $\mathrm{mm}^{3}$, and platelets $525,000 / \mathrm{mm}^{3}$. There were abnormal findings in routine blood tests: serum electrolytes were generally low, BUN was $33 \mathrm{mg} / \mathrm{dL}$, and CRP $58.6 \mathrm{mg} / \mathrm{L}$; the IgG level was $3059.8 \mathrm{mg} / \mathrm{dL}(\mathrm{N}: 700-1600)$ and the $\mathrm{IgA}$ level $502.9 \mathrm{mg} / \mathrm{dL}(\mathrm{N}: 70-400)$. On serological examination, there was no evidence of HIV infection. 
Abdominopelvic ultrasound showed hepatosplenomegaly while PET revealed cervical, supraclavicular, axillary, mediastinal-hilar, intraabdominal, bilateral inguinal and femoral multifocal lymphadenopathy in addition to bilateral pleural effusion. The largest lymph node was in the right axillary with a size of 30x18 mm and SUVmax of 3.3.

On evaluation of the resected right axillary lymph node specimen measuring $23 \times 13 \times 7 \mathrm{~mm}$, serial sections were graywhite colored and a nodular appearance was remarkable. In the sections of the total processed lymph node, the normal structure was partially preserved and lymphoid follicle structures (CD20 and PAX5 positive) of varying shapes and sizes, including some atrophic germinal centers (CD21 and CD23 positive, Bcl-2 negative) were observed (Figure 1). In some of the germinal central structures, it was seen that lymphoid cells were decreased and hyalinized. Plasmablast-like cells were notable in some of these areas (Figure 2). HHV-8 and EBV positivity was noted by in situ hybridization (EBER) in some of these cells and in a small number of cells in the mantle zone (Figure 3,4). In some follicle structures, a concentric arrangement in the mantle zone areas and vascular structure penetrating into the germinal center were noteworthy (Figure 5). Occasionally,

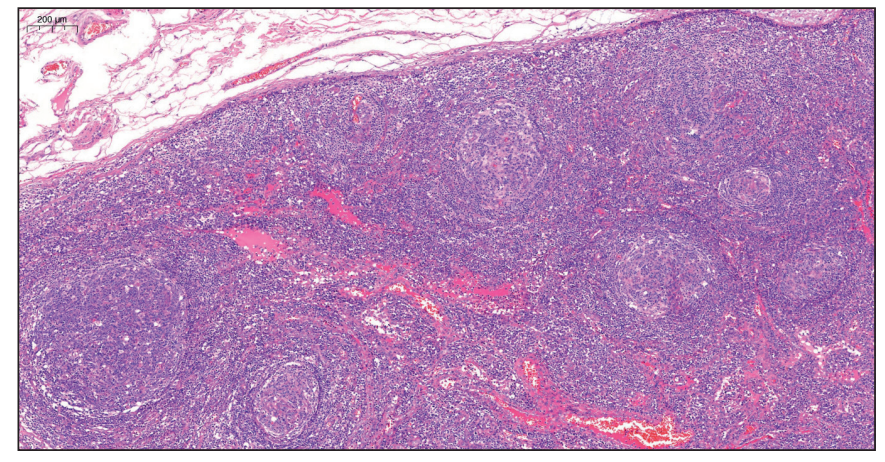

Figure 1: Microscopic examination of lymph node, lymphoid follicle structures of varying shapes and sizes (H\&E stain, $\mathrm{x} 4$ ).

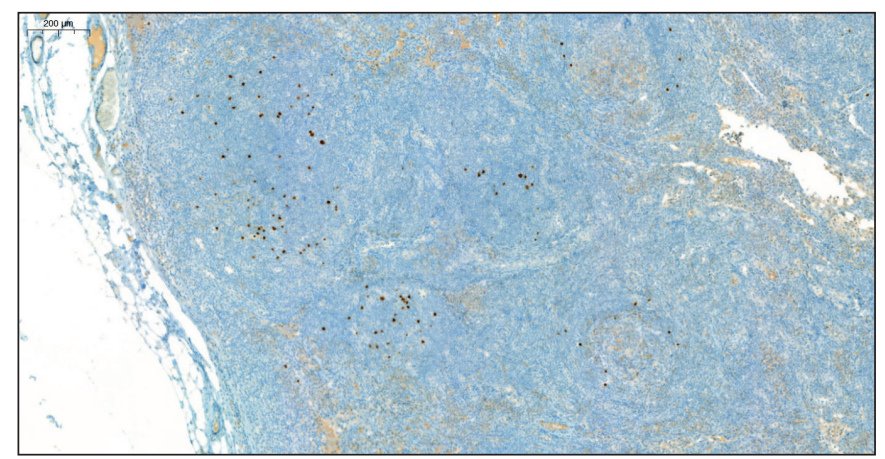

Figure 3: HHV-8 positive cells in the germinal center and mantle zone (HHV-8 Immunohistochemistry, x5). interfollicular areas were enlarged. In these areas, mostly CD3 positive $\mathrm{T}$ lymphocytes as well as CD38 positive plasma cells, some of which formed large aggregates, and marked vascular proliferation in the endothelium were seen (Figure 6). Although plasma cells and plasmablast-like cells were predominantly lambda positive, some of them were positive with lambda and some with kappa.

Finally the case was reported as "HHV-8 and EBV Positive Lymphoproliferative Disease" instead of giving a definite diagnosis. Two cycles of Rituximab one month apart were administered to the patient.

\section{DISCUSSION}

Kaposi sarcoma associated herpesvirus (KSHV), also known as HHV-8, is a lymphotropic virus and associated with 4 lymphoproliferative diseases: primary effusion lymphoma (PEL), HHV-8 positive multicentric Castleman disease (MCD), HHV-8-positive diffuse large B-cell lymphoma and rarely germinotropic lymphoproliferative disorder (GLPD) (2).

PEL presents as serous effusion in body cavities (peritoneal, pleural and pericardial) or solid tumour without effusion ("solid" PEL) and occurs in immunodeficient patients with

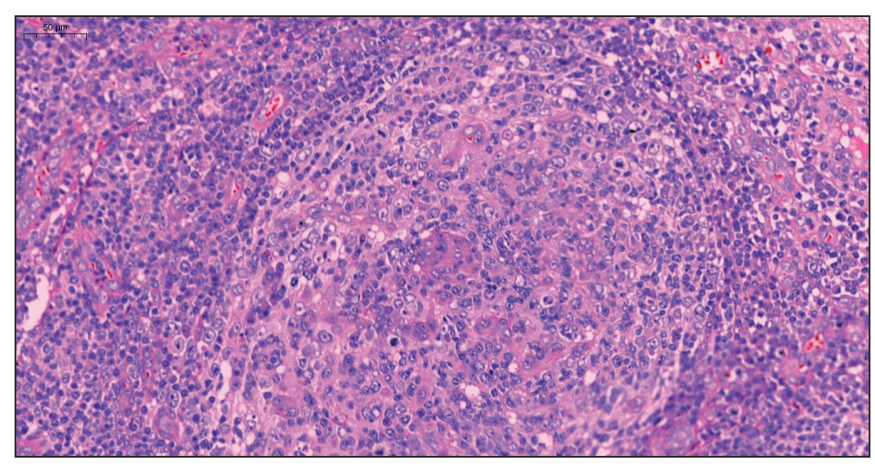

Figure 2: Hyalinized germinal center including plasmablast-like cells (H\&E stain, $\mathrm{x} 20)$.

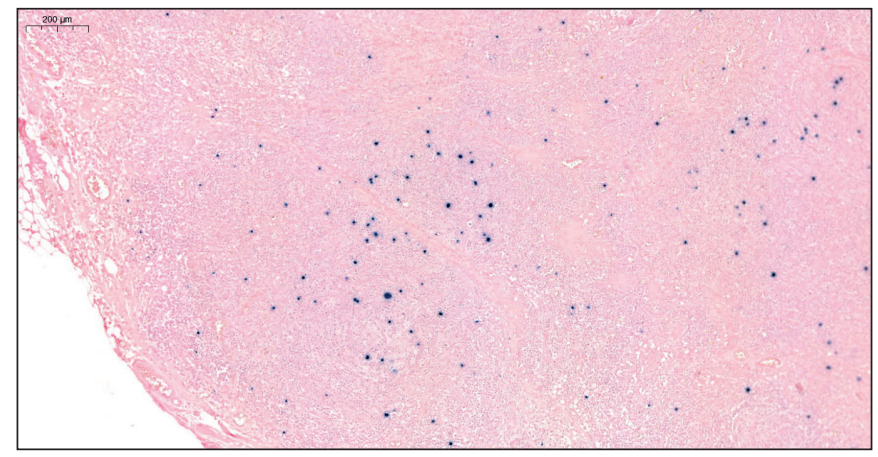

Figure 4: EBV positive cells in the germinal center and mantle zone by in situ hybridization (CISH EBER, x5). 


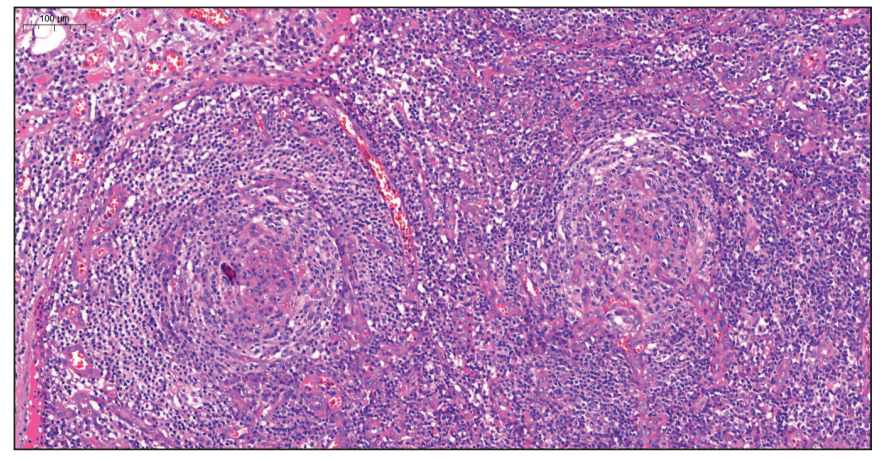

Figure 5: Concentric arrangement in the mantle zone areas and vascular structure penetrating into the germinal center $(\mathrm{H} \& \mathrm{E}$ stain, $\mathrm{x} 10)$.

HIV infection. Infected patients have systemic symptoms and prognosis is poor (5). That patients have HHV-8 and EBV positive immunoblasts with plasmacytoid cytoplasm and pleomorphic nuclei. PEL differs from GLPD in the absence of cytoplasmic immunoglobulin expression (6).

Castleman disease (CD) describes 4 diseases: unicentric CD, HHV-8 associated MCD, POEMS associated MCD, idiopathic -who are negative for HHV-8 and HIV-MCD $(7,8)$. MCD is characterized by enlarged lymph nodes in multiple regions and spleen involvement. It is a systemic disease and involves hepatomegaly, splenomegaly, constitutional symptoms and cytopenias (9). HHV-8 associated MCD occurs in most commonly HIV positive patients but HIV negative patients have also been reported (10). Histopathology is prominent, includes hyperplastic/ atrophic germinal centers and hypervascularization; plasmablasts generally located in mantle zones $(11,12)$.

GLPD is a rare HHV-8 associated lymphoproliferative disorder, first described in 3 cases in 2002 by Du et al. and followed by 15 more case reports (12) (Table I). It presents as localized lymphadenopathy and on histopathological examination it is characterized by an infiltration of germinal centers by plasmablastic cells, which are coinfected by HHV-8 and EBV. Migration of neoplastic B-lymphocytes into germinal centers may be the origin of plasmablasts in GLPD. The presence of the atypical plasma cells in the mantle zone and interfollicular area supports this theory. In addition to plasmablastic cells, residual follicle centers can be seen. There are sometimes atrophic follicles similar to MCD. GLPD responds well to chemotherapy and radiotherapy.

In keeping with these features, the possibilities of "HHV8 Positive Multicentric Castleman Disease" and "HHV-8 Positive Germinotropic Lymphoproliferative Disorder" were considered in the differential diagnosis of our case.

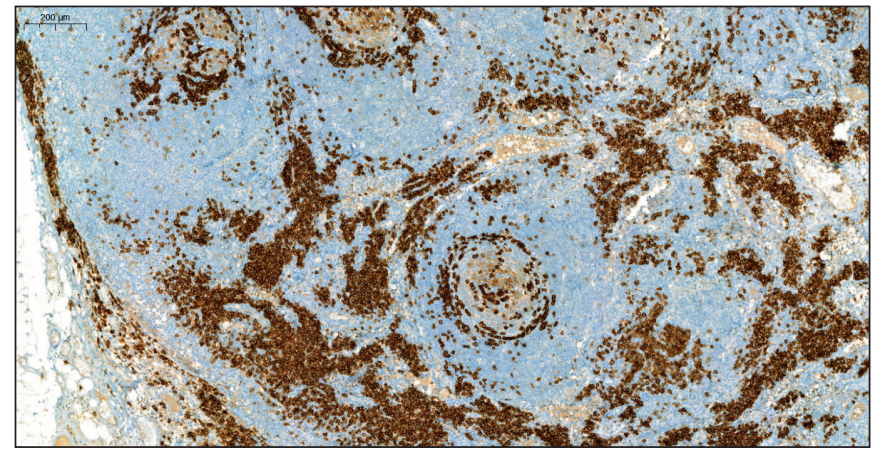

Figure 6: CD38 positive plasma cells forming large aggregates in interfollicular areas (CD38 Immunohistochemistry, x5).

Although MCD and GLPD are two distinct diseases, similar/overlapping histopathological features can be seen in these two entities (Table II).

As MCD progresses with systemic involvement, the multiple lymph node involvement and systemic symptoms in our patient primarily directed us to a diagnosis of MCD. Although GLPD usually presents as localized and sometimes multifocal lymphadenopathy (12), a few cases with symptoms such as mild splenomegaly and systemic symptoms have been reported $(10,11)$.

Since GLPD is mostly seen in HIV-negative immunocompetent patients, we may consider the HIV negativity in favor of GLPD in our patient. However there is also a 58-year-old HIV-positive patient who was diagnosed with GLPD in the literature (11). In addition, an HIV-negative HHV-8 positive subgroup of MCD, which occurs mostly in immunosuppressive patients, has also been identified (10). Therefore, the HIV status of the patient is not a reliable criterion in distinguishing these two diseases.

Some features described in microscopic findings (plasmablast-like cells, atrophic germinal centers, decreased lymphoid cells, hyalinization etc.) overlap with both entities but the presence of a concentric arrangement in the mantle zone strengthens the diagnosis of MCD.

Another important point according to all published GLPD cases in the literature is that HHV-8 and EBV co-infection is one of the most significant criteria that differentiates GLPD from MCD (11-16). However, in an article published by Nobel et al. in 2019, EBV positivity was detected in two of two HHV-8 positive MCD patients included in the study (17). This newly defined condition, the presence of EBV positivity in MCD, will cause serious difficulties in distinguishing these two diseases, as in our case (18-19). 
Table I: Clinicopathological features of patients diagnosed with germinotropic lymphoproliferative disorder

\begin{tabular}{|c|c|c|c|c|c|}
\hline & $\begin{array}{l}\text { Age/ } \\
\text { Sex }\end{array}$ & $\begin{array}{c}\text { Clinical } \\
\text { Presentation }\end{array}$ & HIV & $\begin{array}{l}\text { Ig heavy/light } \\
\text { chain expression }\end{array}$ & Treatment and Prognosis \\
\hline $\begin{array}{l}\text { Case } 1 \\
(12)\end{array}$ & $41 \mathrm{y} / \mathrm{M}$ & $\begin{array}{c}\text { Axillary and cervical lymph node } \\
\text { enlargement for } 6 \text { years }\end{array}$ & - & $\begin{array}{c}\text { Lambda } \\
\text { cIgM, cIgD }\end{array}$ & $\begin{array}{c}\text { CHOP } \\
\text { Complete remission }\end{array}$ \\
\hline $\begin{array}{l}\text { Case } 2 \\
(12)\end{array}$ & $61 \mathrm{y} / \mathrm{M}$ & $\begin{array}{c}\text { Submandibular and inguinal lymph } \\
\text { node enlargement for } 4 \text { years } \\
\text { Slightly enlarged spleen }\end{array}$ & - & $\begin{array}{l}\text { Lambda } \\
\text { cIgA }\end{array}$ & $\begin{array}{l}\text { Excision and radiotherapy } \\
\text { Complete remission }\end{array}$ \\
\hline $\begin{array}{l}\text { Case } 4 \\
(12)\end{array}$ & $60 \mathrm{y} / \mathrm{M}$ & Localized cervical lymphadenopathy & - & $\begin{array}{l}\text { Kappa } \\
\text { cIgM }\end{array}$ & $\begin{array}{c}\text { Excision } \\
\text { No evidence of relaps }\end{array}$ \\
\hline $\begin{array}{l}\text { Case } 7 \\
(15)\end{array}$ & $49 \mathrm{y} / \mathrm{F}$ & Right jugulo-cervical nodal mass & - & Lambda & $\begin{array}{c}\text { Excision and radiotherapy } \\
\text { Complete remission }\end{array}$ \\
\hline $\begin{array}{l}\text { Case } 8 \\
(11)\end{array}$ & $84 y / F$ & Multifocal lymphadenopathy & - & None & $\begin{array}{c}\text { CHOP } \\
\text { Complete remission }\end{array}$ \\
\hline $\begin{array}{l}\text { Case } 9 \\
(11)\end{array}$ & $58 \mathrm{y} / \mathrm{M}$ & $\begin{array}{c}\text { Localized right axillary mass for } \\
10 \text { years } \\
\text { Mild splenomegaly }\end{array}$ & + & None & $\begin{array}{l}\text { Resection } \\
\text { One year later developed DLBCL, died } \\
\text { due to his disease subsequent }\end{array}$ \\
\hline $\begin{array}{l}\text { Case } 12 \\
(22)\end{array}$ & $53 y / M$ & Swelling of cervical nodes & - & $\mu$ & NI \\
\hline $\begin{array}{l}\text { Case } 13 \\
(14)\end{array}$ & $86 y / M$ & Localized cervical lymphadenopathy & - & Kappa & $\begin{array}{c}\text { Without therapy } \\
\text { No evidence of relapse }\end{array}$ \\
\hline $\begin{array}{l}\text { Case } 14 \\
(14)\end{array}$ & $52 \mathrm{y} / \mathrm{M}$ & $\begin{array}{c}\text { Inguinal lymph node enlargement } \\
\text { for } 3 \text { years }\end{array}$ & - & None & CHOP \\
\hline $\begin{array}{l}\text { Case } 15 \\
(14)\end{array}$ & $47 \mathrm{y} / \mathrm{M}$ & $\begin{array}{l}\text { Generalized lymphadenopathy } \\
\text { B Symptoms }\end{array}$ & + & None & CHOP \\
\hline $\begin{array}{l}\text { Case } 16 \\
(14)\end{array}$ & $27 \mathrm{y} / \mathrm{M}$ & $\begin{array}{c}\text { Generalized lymphadenopathy } \\
\text { B Symptoms }\end{array}$ & + & Kappa & Rituximab \\
\hline $\begin{array}{l}\text { Case } 17 \\
(14)\end{array}$ & $30 \mathrm{y} / \mathrm{M}$ & $\begin{array}{c}\text { Generalized lymphadenopathy } \\
\text { B Symptoms }\end{array}$ & + & Kappa & R-DA-EPOCH \\
\hline $\begin{array}{l}\text { Case } 18 \\
(14)\end{array}$ & $42 \mathrm{y} / \mathrm{M}$ & $\begin{array}{l}\text { Generalized lymphadenopathy } \\
\text { B Symptoms }\end{array}$ & + & Lambda & R-DA-EPOCH \\
\hline
\end{tabular}

NI: No information, DLBCL: Diffuse Large B Cell Lymphoma, CHOP: Rituximab, cyclophosphamide, doxorubicin, vincristine, prednisone, EPOCH: Etoposide, prednisone, vincristine, cyclophosphamide, doxorubicin, R-DA-EPOCH: Rituximab, vincristine, adriamycin, cyclophosphamide, methylprednisolone. 
Table II: Comparison of the clinical and pathological features of HHV-8 positive MCD and GLPD

\begin{tabular}{lll}
\hline $\begin{array}{l}\text { Clinical } \\
\text { Presentation }\end{array}$ & HHV-8 Positive MCD & HHV-8 Positive GLPD \\
& $\begin{array}{l}\text { Mostly in HIV positive immunodeficient } \\
\text { Generalized lymphadenopathy, splenomegaly, } \\
\text { constitutional symptoms }\end{array}$ & $\begin{array}{l}\text { Predominantly in HIV negative immunocompetent } \\
\text { patients } \\
\text { Often localized lymphadenopathy } \\
\text { Sometimes multifocal lymph node involvement and } \\
\text { rarely systemic symptoms }\end{array}$ \\
\hline Prognosis & Poor prognosis & $\begin{array}{l}\text { Usually favorable response to chemotherapy and } \\
\text { radiotherapy }\end{array}$ \\
\hline $\begin{array}{l}\text { Microscopic } \\
\text { Findings }\end{array}$ & $\begin{array}{l}\text { Abnormal follicle structures } \\
\text { Plasmablasts generally located in the mantle } \\
\text { zone but they may intrude into germinal } \\
\text { centers }\end{array}$ & $\begin{array}{l}\text { Residual follicle centers can be seen } \\
\text { Plasmablasts partially/completely invade germinal } \\
\text { centers }\end{array}$ \\
Atrophic or hyperplastic germinal centers & Sometimes atrophic follicles similar to MCD \\
& $\begin{array}{l}\text { Prominent vascular proliferation } \\
\text { Concentric onion skin-like layering }\end{array}$ & \\
\hline EBER & Plasma cell hyperplasia in interfollicular area & \\
\hline HIV & Positive/Negative & Always positive \\
\hline $\begin{array}{l}\text { Cytoplasmic Ig } \\
\text { Heavy Chain }\end{array}$ & Usually positive, rarely negative & Predominantly negative, rarely positive \\
\hline Ig Light Chain & Movated, only IgM & Elevated, any heavy chain \\
\hline $\begin{array}{l}\text { Clonality (Ig gene } \\
\text { rearrangements) }\end{array}$ & Polyclonal & Monotypic kappa or lambda + \\
\hline Mutated Ig Genes & Absent & Polyclonal/Oligoclonal \\
\hline Cell of Origin & A naive B cell & Present \\
\hline
\end{tabular}

Due to the reasons described above and the morphologically similar features, it is very difficult to distinguish between the two entities only by histopathological examination. At this point, the importance of clinicopathological correlation becomes more evident, especially in the determination of the treatment protocol applied to the patient. The physical examination and laboratory findings should also be evaluated in detail and carefully.

\section{Conflict of Interest}

The authors declare no conflict of interest.

\section{Authorship Contributions}

Concept: GB, GG, Design: GB, GG, Data collection or processing: GB, GG, MAÖ, SÖ, Analysis or Interpretation: GB, GG, MAÖ, SÖ, Literature search: GB, GG, Writing: GB, GG, Approval: SÖ.

\section{REFERENCES}

1. Courville EL, Sohani AR, Hasserjian RP, Zukerberg LR, Harris NL, Ferry JA. Diverse clinicopathologic features in human herpesvirus 8-associated lymphomas lead to diagnostic problems. Am J Clin Pathol. 2014;142:816-29.

2. Guerrero C, Jain T, Kelemen K. HHV-8-associated lymphoproliferative disorders and pathogenesis in an HIVpositive patient. Case Rep Hematol. 2019;2019:4536157.

3. Chen CH, Liu HC, Hung TT, Liu TP. Possible roles of EpsteinBarr virus in Castleman disease. J Cardiothorac Surg. 2009;4:31.

4. Taris M, de Mascarel A, Riols M, Delwail V, Milpied N, Dubus P, Parrens M. KHSV/EBV associated germinotropic lymphoproliferative disorder: A rare entity, case report and review of the literature. Ann Pathol. 2014;34:373-7.

5. Nador RG, Cesarman E, Chadburn A, Dawson DB, Ansari MQ, Said J, Knowles DM. Primary effusion lymphoma: A distinct clinicopathologic entity associated with the Kaposi's sarcomaassociated herpes virus. Blood. 1996;88:645-56. 
6. Dupin N, Diss TL, Kellam P, Tulliez Micheline, Du MQ, Sicard D, Weiss RA, Isaacson PG, Boshoff C. HHV-8 is associated with a plasmablastic variant of Castleman disease that is linked to HHV-8-positive plasmablastic lymphoma. Blood. 2000;95:140612.

7. van Rhee F, Greenway A, Stone K. Treatment of Idiopathic Castleman Disease. Hematol Oncol Clin North Am. 2018;32:89106.

8. Dispenzieri A, Fajgenbaum DC. Overview of castleman disease. Blood. 2020;135:1353-64.

9. Waterston A, Bower M. Fifty years of multicentric Castleman's disease. Acta Oncol. 2004;43:698-704.

10. Wang H, Pittaluga S, Jaffe ES. Multicentric Castleman disease: Where are we now? Semin Diagn Pathol. 2016;33:294-306.

11. Bhavsar T, Lee JC, Perner Y, Raffeld M, Xi L, Pittaluga S, Jaffe ES. $\mathrm{KSHV}$ - and EBV-associated germinotropic lymphoproliferative disorder: New findings and review of the literature. Am J Surg Pathol. 2018;41:795-800.

12. Du MQ, Diss TC, Liu H, Ye H, Hamoudi RA, Cabeçadas J, Dong HY, Harris NL, Chan JKC, Rees JW, Dogan A, Isaacson PG. KSHV- and EBV-associated germinotropic lymphoproliferative disorder. Blood. 2002;100:3415-8.

13. Swerdlow SH, Campo E, Harris N, Jaffe ES, Pileri SA, Stein H, Thiele J. World Health Organization Histological Classification of Tumors of Haematopoietic and Lymphoid Tissues. 4th ed. IARC Press; 2017.

14. Gonzalez-Farre B, Martinez D, Lopez-Guerra M, Xipell M, Monclus E, Rovira J, Garcia F, Lopez-Guillermo A, Colomo L, Campo E, Martinez A. HHV8-related lymphoid proliferations: A broad spectrum of lesions from reactive lymphoid hyperplasia to overt lymphoma. Mod Pathol. 2017;30:745-60.

15. Oh J, Yoon H, Shin DK, Jang MJ, Kim G, Chong SY, Oh D. A case of successful management of HHV-8 +, EBV + germinotropic lymphoproliferative disorder (GLD). Int J Hematol. 2012;95:10711.
16. Antonio D, Amedeo B, Maria A, Angel PM, Oscar N. KSHVand EBV-associated germinotropic lymphoproliferative disorder: A rare lymphoproliferative disease of HIV patient with plasmablastic morphology, indolent course and favourable response to therapy. Leuk Lymphoma. 2007;48:1444-7.

17. Nabel CS, Sameroff S, Shilling D, Alapat D, Ruth JR, Kawano M, Sato Y, Stone K, Spetalen S, Valdivieso F, Feldman MD, Chadburn A, Fosså A, van Rhee F, Lipkin WI, Fajgenbaum DC. Virome capture sequencing does not identify active viral infection in unicentric and idiopathic multicentric Castleman disease. PLoS ONE. 2018;14:1-13.

18. Zanelli M, Zizzo M, Bisagni A, Froio E, Marco LD, Valli R, Filosa A, Luminari S, Martino G, Massaro F, Fratoni S, Ascani S. Germinotropic lymphoproliferative disorder: A systematic review. Ann Hematol. 2020;99:2243-53.

19. Nakaya Y, Ishii N, Kasamatsu Y, Shimizu K, Tatsumi N, Tsutsumi M, Yoshida M, Yoshimura T, Hayashi Y, Nakao T, Inoue T, Yamane T. Human herpesvirus 8-positive multicentric Castleman disease with germinotropic plasmablastic aggregates: Overlapping spectrum of human herpesvirus 8-associated lymphoproliferative disorder. Pathol Int. 2020;70:574-80.

20. D’Antonio A, Addesso M, Memoli D, Liguori P, Cuomo R, Boscaino A, Nappi O. Lymph node-based disease and HHV-8/ KSHV infection in HIV seronegative patients: Report of three new cases of a heterogeneous group of diseases. Int J Hematol. 2011;93:795-801.

21. Zanelli M, Fraternali Orcioni G, Zizzo M, Marco LD, Martino G, Cerrone G, Cabras AD, Ascani S. HHV-8- and EBV-positive germinotropic lymphoproliferative disorder. Ann Hematol. 2019;98:2439-41.

22. Papoudou-Bai A, Hatzimichael E, Kyriazopoulou L, Briasoulis E, Kanavaros P. Rare variants in the spectrum of human herpesvirus 8/Epstein-Barr virus-copositive lymphoproliferations. Hum Pathol. 2015;46:1566-71. 